\title{
A PRELIMINARY STUDY OF THE TAXANE CHEMISTRY AND NATURAL history of the MeXican yeW, Taxus globosa SchltDl.
}

\author{
Melvin J. Shemluck ${ }^{1}$, Eduardo Estrada², Robert Nicholson ${ }^{3}$ and Susan W. Brobst ${ }^{4}$ \\ ${ }^{1}$ Quinsigamond College, 670 W. Boylston, St. Worcester, MA. 01606. \\ Phone: 508-854-4299. Fax: 508-852-6943. E-mail: mels@qcc.mass.edu \\ 2 Facultad de Ciencias Forestales, Universidad Autónoma de Nuevo León, \\ A.P. 41 60700, Linares, Nuevo León, México. E-mail: aeduardoestrada@prodigy.net.mx \\ ${ }^{3}$ Botanical Garden of Smith College, Northampton, MA. 01063. \\ Phone: 413-585-2748. Fax: 413-585-2744. E-mail: rnichols@smith.edu \\ ${ }^{4}$ Frederick Cancer Research and Development Center, P.O. Box B, Frederick, MD, 21702
}

\begin{abstract}
This paper represents a preliminary study of the botany, natural history and taxane chemistry of the Mexican yew, Taxus globosa Schltdl. Taxonomic history, morphological comparison to other North American species and ecological habitat are discussed. Chemical study involved leaf and twig material from forty-nine plants from three localities in Mexico. Levels of taxol, cephalomannine and baccatin III were determined by HPLC analysis. Intrapopulational variation was found to be very high while mean taxane levels for each of the three populations were very similar. The average percentage of taxol in leaves of T. globosa is higher than in all other species of Taxus $(0.0121 \%$ dry wt.).
\end{abstract}

Key words: Taxus globosa, Mexican yew, taxane composition, taxonomy, conservation, economic botany.

Resumen: Este trabajo representa un estudio preliminar de la botánica, la historia natural y la química del taxano del tejo mexicano, Taxus globosa Schltdl. Se discute la historia taxonómica, la ecología del hábitat y la comparación morfológica con las otras especies de Norteamérica. El estudio comprendió material foliar y ramas de 49 plantas provenientes de tres localidades de México. Los niveles de taxol, cefalomanina y bacatina III fueron determinados mediante el análisis HPLC. Se encontró una variación intrapoblacional muy alta, mientras que los niveles medios de taxano fueron muy similares en las tres poblaciones. El porcentaje promedio de taxol en hojas de T. globosa es mayor que en las otras especies de Taxus (0.0121\% del peso seco). Palabras clave: Taxus globosa, tejo mexicano, composición de taxano, taxonomía, conservación, botánica económica.

$\mathbf{T}$ he economic usage of Taxus species (yew) in North America dates back into pre-columbian civilizations. Woods of the various North American species were utilized to make weaponry, tools, culinary objects, sporting equipment as well as art and devotional objects. Taxus canadensis of eastern North America and Taxus brevifolia of the Pacific Northwest were used medicinally by a number of indigenous peoples for such ailments as rheumatism, clots, scurvy, paralysis, gonorrhea, and lung ailments (Hartwell, 1991).

With the approval in 1992 of the compound taxol for treating human cancer cells, the economic usage of this genus entered a new phase. Plants were harvested from the wild in the Pacific Northwest of the United States to supply an exploding demand for the natural compound taxol, found in the bark in minute percentages. When ecological concerns were voiced, the harvesting of wild trees was shifted to Asian species, primarily in India and China. Discussions are now taking place to include various Taxus species as CITES listed plants due to the over-harvesting to supply pharmaceutical firms. To date an economical method for synthesizing taxol has not been found, but a partial synthesis, utilizing the taxane compound baccatin III is now a commercially viable method of producing this anti-cancer compound. Annual sales of taxol now total into the hundreds of millions of dollars (U.S.). An examination of the taxane chemistry and ecological characteristics of Taxus globosa was undertaken to determine the potential of this species as a new economic crop; a plantation production of source material for the extraction of anti-cancer compounds.

Of the four yews native to the Western Hemisphere, the most poorly known is the Mexican yew, Taxus globosa 
Schltdl. It ranges from Central Nuevo León State in Mexico sporadically as far south as Guatemala, Honduras and El Salvador. Since its initial discovery, the species has been sporadically collected and has remained obscure in literature and rare in cultivation. Its relative rarity has probably spared Taxus globosa from commercial harvesting for the international bark market.

The authors have found T. globosa in a range of altitudes and habitats and associated with a wide assortment of species. Its habit is variable, appearing as a multistemmed shrub of up to $8 \mathrm{~m}$ and as a single stemmed tree to $20 \mathrm{~m}$.

This investigation represents the second study (Wheeler et al., 1992) in which native populations of Taxus are surveyed for their taxane levels. The objectives of this study were to determine: (1) What is the range of Taxus globosa, what are the habitats that $T$. globosa can be found in, and what are some of its associated species?, (2) How can $T$. globosa be taxonomically distinguished from other species of North American Taxus?, (3) What levels of taxane compounds are found in T. globosa?, (4) What is the degree of variation of the level of these compounds within a single stand of T. globosa?, (5) Does marked variation in taxane levels exist between stands?, (6) Are taxane levels tied to age, sex, or environmental conditions?, and (7) How does $T$. globosa compare to other species of Taxus in regards to taxane compound levels?

\section{Materials and methods}

Herbarium and literature search. A search of four major U.S. herbaria (Gray, Missouri, Field and Smithsonian) and written accounts (Puig et al., 1987; Hernández et al., 1951), provided us with population localities to which we added locations from our field work.

Collection sites. With a grant from the National Cancer Institute (NCI), Estrada, Nicholson and Shemluck began preliminary investigations into this species in the autumn of 1990. Forty-nine samples of foliage and stem material were collected from three populations, over a distance of $270 \mathrm{~km}$. Sampling was based on an estimation of the size of study area and transects which would inventory as much variation in plant size and habitat as possible in a limited amount of time.

Sample collection. Stems up to four years in age, together with their needles were collected and stored in polyethylene bags. Over the ten days of collecting these samples were continuously cooled by refrigeration or kept in ice chests. All sampled plants were tagged and notes were taken on light conditions of the site (when possible), habitat, plant size, habit, sex, and whether the plant had been subjected to browsing by animals or trimming by man (for fence posts, etc.). Upon arrival in the United States all samples were processed and sent for analysis within three days of their arrival. Samples were collected in Mexico under permit no. 301849, issued by the Mexican Secretariat of Foreign Affairs.

Collection Site1, Central Nuevo León State-- Nineteen random collections of needles and stem branches (three years or less) were made over a transect of approximately $13 \mathrm{~km} . T$. globosa was found in both mixed deciduous forest and spruce-fir coniferous forest. The altitudinal range was from $1390 \mathrm{~m}$ to $2200 \mathrm{~m}$. Four stands were sampled within this site with the largest plant $15 \mathrm{~m}$ high and $0.3 \mathrm{~m}$ diameter at breast height (DBH).

Associated species in the site include: Abies vejarii, Cornus floridana var. urbiniana, Ilex sp., Juglans sp., Ostrya virginiana, Picea martinezii, Pinus sp., Rosa mexicana, and Tilia houghii. The flora could best be described as cool-temperate forest with a number of disjunct elements from the forest of the northeastern United States. For example, Patterson (1988) writing about this area in terms of a new species of spruce stated:

("Heavy rainfall, frequent fog, and a sheltered environment apparently have allowed this spruce community to persist”.)

Consequently even though climatological data are not available for this precise area the microclimate conditions suggest a higher rainfall and humidity than the immediate surrounding area.

Collection Site 2, Southern Nuevo León State, 160 km south of Site 1.- Twenty collections of needles and stems (three years or less) were made over a transect of $14 \mathrm{~km}$ with the altitudinal range from 2040 to $2540 \mathrm{~m}$. Four specific stands were sampled within a habitat of oak-pine forest. The largest yews at this site were $7 \mathrm{~m}$ tall and $23 \mathrm{~cm}$ DBH. It should be noted that Taxus globosa is a favorite wood used by local farmers for the construction of fenceposts and there was evidence of this activity at this site. (We have learned that since our visit, some of our sampled plants have since been cropped for fence posts.)

Associated species at this site include: Arbutus xalapensis, Cupressus lusitanica var. benthamii, Ilex sp., Ostrya virginiana, Paxistima sp., Pinus strobiformis, Quercus spp., Pseudotsuga menziesii and Vaccininum conferta. Overall, the forest at this site appeared drier than Site 1. Taxus globosa was found in the coolest and most moist microclimates of Site 2.

Collection Site 3, Southwestern Tamaulipas State, $110 \mathrm{~km}$ south of Site 2.- Nine collections of needles and stems were made over a $5-\mathrm{km}$ transect with an altitudinal range from $1260 \mathrm{~m}$ to $1485 \mathrm{~m}$. Climate data from this region are known (Puig et al., 1987) and are described as "cloud forest" with heavy, frequent fog. The minimum annual temperature is $-2^{\circ} \mathrm{C}$ while the maximum temperature is $34.4^{\circ} \mathrm{C}$, with 252 $\mathrm{cm}$ of rainfall per year. This area may represent the northernmost cloud forest habitat on the eastern coast of North America. 
Associated species at this site include: Acer skutchii, Carya ovata, Chamaedora radicaulis, Clethra pringlei, Fagus grandifolia, Illicium mexicana, Ilex sp., Liquidambar styraciflua, Magnolia tamaulipana, Podocarpus reichii, Quercus germana, Ternstroemia sylvatica, Tilia houghii. At the altitudinal range where yews were found, the dominant woody plants were Liquidambar styraciflua and Quercus germana.

Taxane analysis. Collected samples were analyzed for taxane levels by Brobst at the Program Resources, Inc. (NCI, Frederick, MD).

General Experimental Procedures.- Instrumentation consisted of a Waters 600E multi solvent Delivery system, Waters WISP 700 Autosampler, and Waters 900+ Photodiode Array Detector with an NEC APCIV computer (Information Systems) for data processing. An IEC Model K Centrifuge was used for centrifugation. A Dynamax Microsorb $5 \mathrm{~mm}$ phenyl column $(4.6 \mathrm{~mm} \times 150 \mathrm{~mm})$ with guard module (Ranin Instrument Company) was used for HPLC analyses. HPLC grade $\mathrm{MeCN}, \mathrm{MeOH}, \mathrm{CH}_{2} \mathrm{Cl}_{2}, \mathrm{C}_{6} \mathrm{H}_{14}$, and $\mathrm{H}_{2} \mathrm{O}$ were purchased from Burdick and Jackson. Standards were weighed on a Cahn 21 automatic electrobalance.

Extraction.- Approximately $10 \mathrm{~g}$ of plant material was extracted in a cylindrical separatory funnel, with $50 \mathrm{ml}$ of hexane for $24 \mathrm{~h}$ at room temperature. This initial "defatting" step was necessary to remove nonpolar material that would interfere with subsequent chromatography. The hexane extract was discarded, and the remaining plant material was extracted with $\mathrm{CH}_{2} \mathrm{Cl}_{2}-\mathrm{MeOH}$ (1:1) for $24 \mathrm{~h}$ at room temperature (Witherup et al., 1990). The resulting organic extract was collected and evaporated to dryness at $35^{\circ} \mathrm{C}$ under reduced pressure in a tared flask. The residue was dissolved in a minimal amount of $\mathrm{MeOH}$ and was partitioned between $\mathrm{CH}_{2} \mathrm{Cl}_{2}$ and $\mathrm{H}_{2} \mathrm{O}$ (1:1). In order to achieve better separation the mixture was centrifuged at $2700 \mathrm{rpm}$ for $5 \mathrm{~min}$. The aqueous layer was discarded, and the organic layer was evaporated to dryness at $35^{\circ}$ under reduced pressure in a tared flask. The residue mass was determined and a $20 \mathrm{mg} / \mathrm{ml}$ solution in $\mathrm{MeOH}$ was prepared and filtered through a $0.2 \mathrm{~mm}$ filter.

Standards.- Baccatin III was provided by Dr. David G.I. Kingston, Virginia Polytechnic Institute, Blacksburg, Virginia. Cephalomannine was isolated in the Program Resources Laboratory from the bark of $T$. brevifolia and was identified based on spectral properties. A taxol reference standard was provided by the Development Therapeutics Program, National Cancer Institute. A $1 \mathrm{mg} / \mathrm{ml}$ solution of each standard in $\mathrm{MeOH}$ was prepared and filtered through a 0.2 mm filter prior to HPLC analysis.

HPLC Method.- The HPLC method is the same procedure as the one previously reported (Witherup et al., 1990). The taxanes of interest were adequately resolved without the use of a gradient. A phenyl-bonded Si gel column was operated under isocratic conditions employing a mobile phase consisting of $\mathrm{MeOH}-\mathrm{MeCN}-50 \mathrm{mM}$ aqueous ammonium acetate buffer adjusted $\mathrm{pH} 4.4$ with HOAc (20:32:48). The flow rate was $1 \mathrm{ml} / \mathrm{min}$, and the effluent was monitored at $228 \mathrm{~nm}$. The injection volumes were $10 \mathrm{ml}$ for the standards and 25 $\mathrm{ml}$ for the plant samples.

Analysis Method.- Peak areas were used to calculate the amount of taxane in the plant sample. Collected samples were analyzed for taxane levels in cooperation with Weyerhauser Corporation and the Program Resources, Incorporated (NCI, Fredrick, MD). Cuttings from each tree sampled were propagated at the Dana Greenhouse of the Arnold Arboretum, Harvard University (Jamaica Plain, MA). Selected samples were also sent to Dr. Mark Schwartz of the Illinois Natural History Survey and Dr. Nan Vance of United States Forest Service for electrophoretic analysis of genetic variation of the populations.

Validation.- Reproducibility of injections expressed as the variation (\%) of injection was $1 \%$. Because an external standard method of calculating the amount of taxane represented by an area was used, linearity is important. Standards were injected at the beginning, middle, and end of each run. Standard curves showed a correlation of 0.99 . Standard curves were developed for every set of analyses.

It is difficult to determine the absolute content of the compounds of interest in crude extracts and therefore difficult to measure with certainty completeness of extraction. As mentioned in a previous study (Wheeler et al., 1992) $\mathrm{CH}_{2} \mathrm{Cl}_{2}-$ $\mathrm{MeOH}(1: 1)$ provided the highest percent extractables and best biological activity in the P-388 (in vitro) cell line assays and it was also used as the extraction solvent in this study.

Spiking studies with known concentrations of taxol, cephalomannine, and baccatin III evaluated with the experimental protocol gave the following percent recoveries: $98 \%$, $97 \%$, and $97 \%$, respectively.

\section{Results}

Distribution of the Mexican yew. We compiled a list of sites in Mexico and Central America where T. globosa has been recorded. In Mexico this includes seven sites in Nuevo León, three in Tamaulipas, one in Veracruz, three in Hidalgo and five in Oaxaca. In Central America we tabulated four sites in Guatemala, one in El Salvador and four in Honduras. This is not intended as a complete range representation of the species, but is presented to illustrate the sporadic distribution of T. globosa and its rarity relative to T. brevifolia and $T$. canadensis.

The latitudinal range of $T$. globosa is from 25\%30' North to $14^{\circ} 21^{\prime}$ North. In contrast, T. baccata of Eurasia and North 
Africa extends as far southward as $33^{\circ}$ North latitude, while the range of some Asian species of Taxus extend beyond the equator into the southern hemisphere.

The altitudinal range is from $3333 \mathrm{~m}$ in the southern portion of the range (Guatemala) to $1050 \mathrm{~m}$ at a site in Tamaulipas State ( $24^{\circ} 30^{\prime}$ latitude North). Mean altitude was calculated from our field data coupled with data from herbarium sheets. When a range of altitude was given, we used the midpoint for our calculations. A mean altitudinal figure of $2396 \mathrm{~m}$ was calculated based on a sample of 18 reports.

Associated species. We compiled a list of woody genera associated with species of North American Taxus for the purpose of comparing what common denominators exist between them and what clues this might provide about the biogeography of the four native species (table 1). The data are drawn from our own observations and from written records. Gaps exist in our knowledge of associates and we indicate these with a question mark in table 1 . For example, we are unsure if Magnolia acuminata, Magnolia fraseri or Liquidambar styraciflua grow with southern populations of $T$. canadensis in mountains of Virginia. (We solicit any data the reader can provide on these uncertainties.) Although this list is far from complete, we can see that $T$. globosa and T. floridana have a greater number of associates in common than T. globosa shares with T. brevifolia or T. canadensis. Phytogeographers have long noted the floristic similarities between the flora of SE United States and the flora of certain areas of Eastern
Mexico. While a jump dispersal from Eastern Mexico to Florida is conceivable, it should be noted that $T$. floridana is one of a large set of endemics in the Appalacicola region including Torreya taxifolia, another member of the Taxaceae. Therefore, it would seem that as a member of a floristic assemblage of long standing, migration of Taxus from the SE United States to Mexico is more probable.

As demonstrated by pollen studies undertaken by Graham (1975) in Veracruz State the floral history of Mexico is a complex one that does not lend itself to simple explanation. Graham's study proved the existence of a temperate flora in Mexico during the Middle Miocene epoch, 15 million years before the present and long before the Pleistocene glaciation. Genera he identified include: Abies, Picea, Liquidambar, Quercus, Myrica, Juglans, Ulmus, Populus, Celtis and Alnus. All are present in Mexico today and many are associates of $T$. globosa.

In an attempt to delineate the habitat and floristic history of the North American species of Taxus, table 1 lists the associated genera of woody plants. Based on floristic data we would deduce a strong phytogenetic connection between the Mexican yew and the Florida yew. Isoenzyme studies and RNA work performed by Vance and Krupkin (1993) utilizing our collections confirm this hypothesis. These studies also indicate some genetic distance between the pair of $T$. globosa and $T$. floridana compared to the pair $T$. canadensis and $T$. brevifolia. This may suggest that Taxus colonized the North American continent in successive waves with $T$. brevifolia

Table 1. Woody genera associated with North American Taxus. $(\mathrm{X}=$ associated, $\mathrm{O}=$ not associated, $?=$ unknown $)$.

\begin{tabular}{|c|c|c|c|c|}
\hline & T. brevifolia & T. canadensis & T. floridana & T. globosa \\
\hline Abies & $X$ & $X$ & $\mathrm{O}$ & $X$ \\
\hline Acer & $X$ & $X$ & $X$ & $X$ \\
\hline Carpinus & $\mathrm{O}$ & $X$ & $X$ & $X$ \\
\hline Cercis & $?$ & $?$ & $x$ & $X$ \\
\hline Cornus & $x$ & $x$ & $x$ & $X$ \\
\hline Cupressus & $?$ & $\mathrm{O}$ & $\mathrm{O}$ & $x$ \\
\hline Fagus & $\mathrm{O}$ & $x$ & $x$ & $x$ \\
\hline Hamamelis & $\mathrm{O}$ & $x$ & $x$ & $x$ \\
\hline Ilex & $\mathrm{O}$ & $x$ & $x$ & $x$ \\
\hline Illicium & $\mathrm{O}$ & $\mathrm{O}$ & $x$ & $x$ \\
\hline Liquidambar & $\mathrm{O}$ & $?$ & $x$ & $x$ \\
\hline Magnolia & $\mathrm{O}$ & $?$ & $X$ & $x$ \\
\hline Nyssa & $\mathrm{O}$ & $X$ & $X$ & $x$ \\
\hline Osmanthus & $\mathrm{O}$ & $\mathrm{O}$ & $X$ & $x$ \\
\hline Ostrya & $\mathrm{O}$ & $X$ & $x$ & $x$ \\
\hline Pinus & $x$ & $X$ & $X$ & $x$ \\
\hline Picea & $x$ & $X$ & $\mathrm{O}$ & $x$ \\
\hline Quercus & $x$ & $X$ & $X$ & $x$ \\
\hline Styrax & $?$ & $\mathrm{O}$ & $x$ & $x$ \\
\hline Tilia & $\mathrm{O}$ & $X$ & $x$ & $x$ \\
\hline Torreya & $x$ & $\mathrm{O}$ & $x$ & $\mathrm{O}$ \\
\hline Tsuga & $x$ & $X$ & $\mathrm{O}$ & $\mathrm{O}$ \\
\hline Vaccinium & $x$ & $x$ & $x$ & $x$ \\
\hline
\end{tabular}


and T. canadensis (or their progenitors) following T. globosa and T. floridana (or their progenitors).

It should be noted that there are temperate and cool-temperate genera that are found in Eastern Asia and Mexico south of the Rio Grande (= Río Bravo). This list includes the genera Abelia, Buddleia, Cleyera, Deutzia, Meliosma and Photinia. This indicates a longstanding relationship between the flora of these two regions and leaves open the possibility that the Taxus species of the lower latitudes of North America and Asia may have a stronger genetic relationship with each other than they do with their relatives to the north (Miranda and Sharp, 1950; Matuda, 1953).

Systematics and morphology. For Taxus, classification and identification of species and cultivars is a very difficult endeavor. K. Rushforth states: "The yews are a group of closely allied allopatric species; it has been said of the T. baccata cultivar 'Adpressa' that it is more distinct from its parent species than are all the other species" (Rushforth,1987).

Character similarity and the absence of solid taxonomic criteria have led some to suggest that we view all plants as subspecies. But, as Rushforth (1987) suggests, this would "scarcely add to our understanding of them". We would still be struggling with identification problems at a subspecies level. Also, this approach would not convey the most likely evolutionary perspective that is to view these plants as allopatric remnants of a once widespread group that today occupies a similar ecological niche.

Taxus globosa was first described by the German botanist, Diederich Franz Leonhard von Schlechtendal in 1838 from material collected by Christian Ehrenberg. Although Schlechtendal himself never saw the plant in the wild, the plant he described was a 20-foot tree growing near Huajalote, Mexico (present location uncertain), and was bearing seed in September.

In his description, Schlechtendal considered the Mexican yew to be very similar to the European yew, Taxus baccata, but possessing a different "fruit" shape. He states that the "fruit" is more spherical and compressed and that this difference is discernible even in young fruits. It is interesting that he was able to comment on arillus shape since he was presumably working only with pressed specimens.

Typically, characters such as leaf length, leaf width, leaf color, branchlet color, horizontal parting of the leaves, presence of a dorsal leaf keel, shape of the leaf apex, arrangement of bud scales, dorsal bud scale keels, shape of the bud scales and shape of the whole bud have been used to distinguish between taxa. However, few of these characters are fixed. Many of these traits are influenced by growing conditions, are difficult to quantify or are functions of drying. For example, the dorsal bud scale keel is often only clearly seen on dried herbarium specimens. Also, leaf edges often recurve upon drying creating a revolute condition that makes leaf shape description and width measurements ambiguous.
In this paper we do not pretend to offer any profound insight into the complexity of Taxus taxonomy. We present our overall impressions from live material of Taxus globosa and compare this to documented, wild collected living material of the other three North American species: T. brevifolia, T. canadensis and T. floridana.

T. globosa is a shrub or small tree up to $20 \mathrm{~m}$, often with a single bole, similar to many other species in the genus. Leaf size and shape is one of the most variable characters in the genus. It is common to see leaves of different size, shape and apex on the same branchlet. Apparently, these characters are highly influenced by environmental conditions in the early stages of leaf development. In $T$. globosa, leaf size is variable with widths from 1.5 to $2.0 \mathrm{~mm}$ and lengths from 20 to $30+\mathrm{mm}$. Leaves tend to have a distinct apical taper and an overall falcate shape that is most similar to T. floridana. When examining herbarium specimens, there is an additional, complicating factor with leaf (and bud scale) characters. As the leaf dries the edges roll up and the edges recurve changing the leaf width and apical taper. Because of this pseudorevolute condition, descriptions of leaf shape and width can be unreliable. However this problem can be avoided with the use of live material. When examining live material, the leaves of $T$. brevifolia show a distinct acuminate tip with a relatively long taper while $T$. globosa apices are more acute, terminating in a triangular mucron. T. floridana apices are similar to the latter, but with an even smaller, more distinct mucron. T. canadensis leaf tips are the most obtuse but also possess a mucron.

The appearance of the leaf undersurface presents an opportunity for comparing Taxus species. In T. globosa this surface is uniform in color with only two very thin dark green lines along the leaf margins. In other yews these marginal lines are wider and the midvein region is darker in color or oftentimes glossy on the midvein region surface. For example, the undersurface of T. brevifolia and T. canadensis display three distinct lines; two marginal lines and one colored midvein region. Between these lines lie more lightly colored (light green), matte surfaced panels that contain rows of stomata. In the genus these stomatal zones range from light green to yellow-green, but are never white. The undersurface of T. floridana is similar to $T$. globosa but the midvein region has a glossier surface.

The number of stomatal rows though not highly diagnostic is of some value in distinguishing the North American species. On average, T. brevifolia has the least with 5-6, while T. canadensis has 7-8, T. floridana has 6-8 and T. globosa has 8-9.

The dorsal surface leaf color of $T$. globosa is a medium green in intensity with a slight bluish tinge. Color as a character must however be used with caution. T. globosa becomes more yellow-green in sunnier locations and if suddenly exposed to full sun, such as along a newly constructed road, will develop a red/brown pigment similar to that seen in many 
other Taxus species growing under high light and winter conditions. There is only a slight dorsal keel in T. globosa.

The shape of the buds and bud scales are very difficult characters to assess and in this paper we elect not to utilize them. We suggest workers be cautious with this character because of the pseudo-revolute condition of the bud scales that can be produced with drying. In addition, late summer conditions (when buds develop), can produce small leaves at the bud base that can be confused with bud scales or can be described as a "less compact" bud.

The aril is very distinctive in $T$. globosa; fatter, rounder and larger than in other species. Often the distal end is truncated giving it a bell-shaped appearance, an observation described in Schlechtendal's (1838) description of the plant.

The overall morphology of $T$. globosa gives it a similar appearance to $T$. floridana. In both plants, leaf texture is soft and pliable, color is similar, leaf length and widths are comparable, leaf shape is tapered and often falcate and leaf apices are apiculate. However, T. floridana possesses a more well defined mucron. These same characters sharply contrast T. globosa with T. canadensis and T. brevifolia.

Taxane levels. This study found a great deal of variation in taxane levels within plants of the same population. Within Site 1 taxol content varied nearly 10 -fold (from $0.0027 \%$ to $0.0220 \%$ ) (table 2). Within Site 2 a 7-fold difference
$(0.0038 \%$ to $0.0260 \%$ ) (table 3 ) and within Site 3 a 10-fold difference was found $(0.0027 \%$ to $0.0270 \%$ ) (table 4$)$. Variation in cephalomannine ranged from 14-fold, 7-fold and 21fold in each of these three populations, respectively. Baccatin III showed a 7-fold, 11-fold and 36-fold variation within these same three sites. Similar looking trees within close proximity to each other can show quite dissimilar levels of various taxanes. For example in Site 3, Plant \# 8 produced $0.0176 \%$, $0.0046 \%$ and $0.0117 \%$ of taxol, cephalomannine and baccatin III while Plant \# 9 a few meters away produce $0.0270 \%$, $0.0470 \%$ and $0.0710 \%$ of the three taxanes, respectively.

Variation between stands was more uniform and would have been even more so had the single highly productive Plant \# 9 of Site 3 not been included in the data. This uniformity is striking considering that the three populations represent three dissimilar sites in a variety of ecological habitats.

Based on the 49 samples, T. globosa has, on average, higher taxol levels when compared to T. baccata, T. brevifolia, T. cuspidata, T. x media and T. floridana (Wheeler et al., 1992). The levels of the other two taxanes sampled are however, lower (table 5). It must be cautioned that these comparisons do not take into account sample size, seasonality and other differences. Nevertheless, if commercial production of taxol in Mexico becomes a goal, cultivation of selected clones of $T$. globosa would be a logical choice for plantation culture in carefully selected areas of Mexico.

Table 2. Taxane chemistry and ecological observations of sampled plants, Site 1 (Central Nuevo León State). Cephal. = Cephalomannine; Bacc III = Baccatin III.

\begin{tabular}{|c|c|c|c|c|c|c|c|c|c|}
\hline $\begin{array}{c}\text { Sample } \\
\text { no. }\end{array}$ & $\begin{array}{l}\text { Altitude } \\
\text { (m) }\end{array}$ & $\begin{array}{c}\text { Taxol } \\
(\%)\end{array}$ & $\begin{array}{c}\text { Cephal. } \\
(\%)\end{array}$ & $\begin{array}{c}\text { Bacc. III } \\
(\%)\end{array}$ & $\begin{array}{l}\mathrm{DBH} \\
(\mathrm{cm})\end{array}$ & $\begin{array}{l}\text { Height } \\
\text { (m) }\end{array}$ & Sex & Sun & Comments \\
\hline 1 & 1392 & 0.0083 & 0.0122 & 0.0058 & 11.4 & 6.0 & $\mathrm{~F}$ & Full & \\
\hline 2 & 1392 & 0.0094 & 0.0150 & 0.0065 & 7.7 & 3.0 & M & & \\
\hline 3 & 1392 & 0.0030 & 0.0058 & 0.0070 & 10.5 & 3.0 & $\mathrm{~F}$ & & \\
\hline 4 & 1392 & 0.0210 & 0.0212 & 0.0099 & 12.7 & 3.9 & $\mathrm{~F}$ & & \\
\hline 5 & 1554 & 0.0220 & 0.0300 & 0.0300 & 15.2 & 4.5 & $M$ & Shade & \\
\hline 6 & 1554 & 0.0048 & 0.0072 & 0.0050 & 7.6 & 3.6 & $\mathrm{~F}$ & & Chopped \\
\hline 7 & 1440 & 0.0130 & 0.0160 & 0.0058 & 10.5 & 1.5 & $\mathrm{~F}$ & Shade & \\
\hline 8 & 1440 & 0.0119 & 0.0192 & 0.0093 & 35.6 & 7.5 & $\mathrm{~F}$ & & \\
\hline 9 & 2136 & 0.0037 & 0.0041 & 0.0067 & 17.8 & 6.0 & $M$ & Full & \\
\hline 10 & 2136 & 0.0027 & 0.0022 & 0.0039 & 22.9 & 9.0 & $\mathrm{~F}$ & Partial & Chopped \\
\hline 11 & 2136 & 0.0052 & 0.0046 & 0.0076 & 3.8 & 2.4 & $\mathrm{~F}$ & Partial & \\
\hline 12 & 2172 & 0.0104 & 0.0093 & 0.0122 & 38.1 & 13.5 & $M$ & Shade & \\
\hline 13 & 2190 & 0.0180 & 0.0320 & 0.0100 & 3.8 & 0.9 & M & Shade & Browsed \\
\hline 14 & 2190 & 0.0053 & 0.0126 & 0.0126 & 6.4 & 3.9 & & Shade & \\
\hline 15 & 2172 & 0.0091 & 0.0086 & 0.0110 & 1.3 & 1.2 & & Partial & \\
\hline 16 & 2202 & 0.0100 & 0.0290 & - & 25.4 & 12.0 & $\mathrm{~F}$ & Full & Debarked \\
\hline 17 & 2196 & 0.0197 & 0.0092 & 0.0128 & 12.7 & 6.0 & & Partial & \\
\hline 18 & 2196 & 0.0033 & 0.0047 & 0.0045 & 15.2 & 4.5 & $M$ & Partial & \\
\hline 19 & 2100 & 0.0039 & 0.0024 & 0.0045 & 30.5 & - & M & Partial & \\
\hline Range & & $\begin{array}{r}0.0027- \\
0.0220\end{array}$ & $\begin{array}{r}0.0022- \\
0.0320\end{array}$ & $\begin{array}{c}0.0039- \\
0.0300\end{array}$ & & & & & \\
\hline Mean & & 0.0097 & 0.0129 & 0.0092 & & & & & \\
\hline SE & & 0.0015 & 0.0022 & 0.0014 & & & & & \\
\hline
\end{tabular}


TAXANE CHEMISTRY AND NATURAL HISTORY OF TAXUS GLOBOSA

Table 3. Taxane chemistry and ecological observations of sampled plants, Site 2 (Southern Nuevo León State). Cephal. = Cephalomannine; Bacc III = Baccatin III.

\begin{tabular}{|c|c|c|c|c|c|c|c|c|c|}
\hline $\begin{array}{c}\text { Sample } \\
\text { no. }\end{array}$ & $\begin{array}{l}\text { Altitude } \\
\text { (m) }\end{array}$ & $\begin{array}{c}\text { Taxol } \\
(\%)\end{array}$ & $\begin{array}{c}\text { Cephal. } \\
(\%)\end{array}$ & $\begin{array}{c}\text { Bacc. III } \\
(\%)\end{array}$ & $\begin{array}{l}\mathrm{DBH} \\
(\mathrm{cm})\end{array}$ & $\begin{array}{l}\text { Height } \\
(\mathrm{m})\end{array}$ & Sex & Sun & Comments \\
\hline 0 & 2040 & 0.0062 & 0.0160 & 0.0102 & 17.8 & 4.8 & $M$ & Partial & Dieback,slope \\
\hline 1 & 2040 & 0.0038 & 0.0063 & 0.0046 & 7.6 & 3.6 & $\mathrm{~F}$ & Partial & Steep slope \\
\hline 2 & 2040 & 0.0110 & 0.0050 & 0.0020 & 17.8 & - & $M$ & Partial & Browsed \\
\hline 3 & 2040 & 0.0053 & 0.0063 & 0.0103 & 22.9 & - & M & Full & Browsed,slope \\
\hline 4 & 2040 & 0.0084 & 0.0156 & 0.0123 & 5.1 & 3.0 & $\mathrm{~F}$ & Full & Browsed \\
\hline 5 & 2295 & 0.0087 & 0.0167 & 0.0112 & 15.2 & 3.6 & $\mathrm{~F}$ & Full & Browsed \\
\hline 6 & 2295 & 0.0195 & 0.0195 & 0.0182 & 2.5 & 1.5 & $\mathrm{~F}$ & Full & Browsed \\
\hline 7 & 2295 & 0.0230 & 0.0195 & 0.0182 & 2.5 & 1.5 & $\mathrm{~F}$ & Full & Browsed \\
\hline 8 & 2295 & 0.0152 & 0.0122 & 0.0177 & 15.2 & - & $\mathrm{F}$ & Partial & \\
\hline 9 & 2295 & 0.0180 & 0.0128 & 0.0124 & 17.8 & 0.6 & $M$ & Partial & Browsed, cut \\
\hline 10 & 2544 & 0.0167 & 0.0141 & 0.0113 & 12.7 & 3.0 & $\mathrm{~F}$ & Partial & \\
\hline 11 & 2544 & 0.0069 & 0.0191 & 0.0113 & & 3.6 & $M$ & Partial & Ungrazed \\
\hline 12 & 2544 & 0.0211 & 0.0161 & 0.0174 & 7.6 & - & $M$ & Partial & \\
\hline 13 & 2544 & 0.0128 & 0.0151 & 0.0126 & 3.8 & 3.6 & $M$ & Partial & \\
\hline 14 & 2544 & 0.0176 & 0.0128 & 0.0137 & 2.0 & 0.8 & $\mathrm{~F}$ & Partial & \\
\hline 15 & 2544 & 0.0070 & 0.0078 & 0.0071 & 22.9 & 0.6 & $\mathrm{~F}$ & Partial & Cut,regrowth \\
\hline 16 & 2256 & 0.0260 & 0.0240 & 0.0060 & 7.6 & 3.6 & $\mathrm{~F}$ & Full & Browsed \\
\hline 17 & 2256 & 0.0059 & 0.0059 & 0.0065 & 21.6 & 6.0 & $M$ & Full & Unbrowsed \\
\hline 18 & 2256 & 0.0078 & 0.0099 & 0.0083 & 12.7 & 6.0 & $\mathrm{~F}$ & Shade & \\
\hline 19 & 2256 & 0.0251 & 0.0272 & 0.0238 & 11.4 & 6.0 & $M$ & Shade & \\
\hline 20 & 2256 & 0.0135 & 0.0286 & 0.0249 & 3.8 & 1.5 & $\mathrm{~F}$ & Partial & \\
\hline Range & & $\begin{array}{r}0.0038- \\
0.0260\end{array}$ & $\begin{array}{c}0.0050- \\
0.0350\end{array}$ & $\begin{array}{r}0.0020- \\
0.0238\end{array}$ & & & & & \\
\hline Mean & & 0.0133 & 0.0155 & 0.0119 & & & & & \\
\hline SE & & 0.0133 & 0.0018 & 0.0013 & & & & & \\
\hline
\end{tabular}

Table 4. Taxane chemistry and ecological observations, Site 3 (Southwestern Tamaulipas State). Cephal. = Cephalomannine; Bacc III = Baccatin III.

\begin{tabular}{|c|c|c|c|c|c|c|c|c|c|}
\hline $\begin{array}{c}\text { Sample } \\
\text { no. }\end{array}$ & $\begin{array}{c}\text { Altitude } \\
(\mathrm{m})\end{array}$ & $\begin{array}{l}\text { Taxol } \\
(\%)\end{array}$ & $\begin{array}{c}\text { Cephal. } \\
(\%)\end{array}$ & $\begin{array}{c}\text { Bacc. III } \\
(\%)\end{array}$ & $\begin{array}{l}\mathrm{DBH} \\
(\mathrm{cm})\end{array}$ & $\begin{array}{l}\text { Height } \\
(\mathrm{m})\end{array}$ & Sex & Sun & Comments \\
\hline 1 & 1485 & 0.0135 & 0.0084 & 0.0150 & 30.5 & 9.0 & $\mathrm{~F}$ & Partial & Forest edge \\
\hline 2 & 1485 & 0.0175 & 0.0111 & 0.0103 & 27.9 & 10.5 & $M$ & Full & \\
\hline 3 & 1470 & 0.0100 & 0.0300 & 0.0290 & 30.5 & 12.0 & $M$ & Shade & \\
\hline 4 & 1455 & 0.0163 & 0.0114 & 0.0177 & 0.6 & 0.7 & & Full & \\
\hline 5 & 1455 & 0.0090 & 0.0050 & 0.0320 & 25.4 & 7.5 & & Full & \\
\hline 6 & 1455 & 0.0131 & 0.0109 & 0.0122 & 20.3 & 12.0 & & Partial & \\
\hline 7 & 1400 & 0.0065 & 0.0085 & 0.0076 & 25.4 & 18.0 & & Full & \\
\hline 8 & 1410 & 0.0176 & 0.0046 & 0.0117 & 2.0 & 1.8 & & Partial & \\
\hline 9 & 1410 & 0.0270 & 0.0470 & 0.0710 & 22.9 & 15.0 & $\mathrm{~F}$ & Partial & \\
\hline Range & & $\begin{array}{r}0.0065- \\
0.0270\end{array}$ & $\begin{array}{r}0.0046- \\
0.0470\end{array}$ & $\begin{array}{r}0.0076- \\
0.0710\end{array}$ & & & & & \\
\hline Mean & & 0.0145 & 0.0152 & 0.0229 & & & & & \\
\hline SE & & 0.0020 & 0.0047 & 0.0067 & & & & & \\
\hline \multicolumn{10}{|c|}{ Bark Analysis (NCI) } \\
\hline & & 0.0060 & 0.0105 & 0.0021 & & & & & \\
\hline \multicolumn{10}{|c|}{ Composite levels in the three sampled populations } \\
\hline Range & & $0.0027-$ & $0.0022-$ & $0.0121-$ & & & & & \\
\hline & & $0.0270-$ & 0.0470 & 0.0144 & & & & & \\
\hline Mean & & 0.0121 & 0.0710 & 0.0129 & & & & & \\
\hline
\end{tabular}


Table 5. Comparison of taxol, cephalomannine and baccatin III levels in Taxus (\% dry wt.) in six species of Taxus.

\begin{tabular}{|c|c|c|c|}
\hline Species & $\%$ Taxol & \%Cephalomannine & \%Baccatin III \\
\hline T. globosa & 0.0121 & 0.0144 & 0.0129 \\
\hline T. baccata ${ }^{1}$ & 0.0088 & 0.0246 & 0.0285 \\
\hline T. brevifolia ${ }^{1}$ & 0.0081 & 0.0093 & 0.0466 \\
\hline T. cuspidata $^{1}$ & 0.0077 & 0.0237 & 0.0322 \\
\hline T. media $^{1}$ & 0.0056 & 0.0242 & 0.0243 \\
\hline T. floridana ${ }^{2}$ & 0.0060 & 0.0033 & 0.0012 \\
\hline
\end{tabular}

${ }^{1}$ Based on data from Wheeler et al. (1992).

${ }^{2}$ Data based on mean of three samples obtained from three-year old stem cutting collected by Rob Nicholson from specimens in the wild (Florida, USA).

Overall, the percentage of taxol found in Taxus globosa compares quite favorably with the amount of taxol found in other species of yew. Wheeler et al. (1992) report a range of $0.002-0.01 \%$ taxol in six different taxa of yew. They reported a range of $0.001-0.005 \%$ taxol from stem tissue. In particular, sample \# 49 from Site 3 of our survey contains a very high level of taxol, cephalomannine and baccatin III when compared to the aforementioned study.

\section{Discussion}

Conservation status of Taxus globosa. The relative scarcity, obscure locations and difficult terrain in which Taxus globosa is found would seem to offer it some protection from exploitation. In one of the three sites visited by the authors, longrange threats from lumbering and immediate problems of coppicing for firewood and fenceposts were observed. At the lower attitudinal range of Site 1 lumber roads had been constructed along with a small sawmill. However, selective cutting of large pines and not clear cutting appears to be the current lumbering practice in this location that would have less devastating impact on the Mexican yew. Nevertheless, yew is a plant much esteemed by local farmers for fence posts and often a multistemmed plant would be found which had resulted from the removal of the main leader trunk. In a sixmonth period between visits at least one of our tagged plants was found to have been cropped. And, since our last visit, the yews at this site have been used for posts to fence off the more rare Picea martinezii, known only from two sites in Mexico (John Fairey, pers. comm.). Site 2 is very inaccessible and only minor cropping by a sparse farming population is in evidence. Site 3 is on protected national lands, but even in this area a branch of one plant was found cut and inserted back into the soil for some reasons we could only speculate upon.

It is the authors' opinion that the scenario seen in Site 1 will be similar to situations occurring in other parts of the world. Roads are built to access a natural resource such as timber or oil and then these same roads create a conduit for an expanding population. At the present time the scarcity and obscurity of the Mexican yew appears to be its salvation. Nevertheless, it is a potentially valuable plant that grows in poor rural areas. For example, there have been unconfirmed reports of yew bark for sale in the medicine markets of Guadalajara.

Future use of Taxus globosa. It would be wasteful to allow the devastation of this important genetic resource. Taxus globosa has evolved to a different set of environmental parameters than its northern counterparts and potentially offers a unique set of genetic traits that could be of great importance for plantation or cell culture. In the long run the survival of this plant will depend on the actions of the Mexican conservation and forestry departments and the ability of botanists and agronomists to "add value" to the species as a potential plantation crop for rural mountain areas or as a narcotic replacement crop.

Since its efficacy as an anti-cancer compound was discovered, taxol has developed into a 3 billion dollar a year pharmaceutical market in the United States. The authors see no reason that Mexico could not become self-sufficient in regards to Taxol production via plantation culture. The wild populations of Taxus globosa are not only a crucial genetic resource for elite selections with high taxane production capability but also stand as environmental "flags", signaling where the species is most competitive in nature, and where plantations would most likely succeed.

\section{Acknowledgements}

We wish to thank Dr. John Fairey and Carl Schoenfeld, without whom our collections would not have been possible. In addition, we are grateful to Dr. J. Marroquín for his assistance in Mexico and to Dr. Gordon Cragg of The National Cancer Institute (USA) for his advice and support.

We dedicate this paper to the memory of Dr. Richard Evans Schultes, who so loved the plants and peoples of Mexico. 


\section{Literature cited}

Graham A. 1975. Late Cenozoic evolution of tropical lowland vegetation in Veracruz, Mexico. Evolution 29:723-735.

Hartwell H. 1991. The Yew Tree; A Thousand Whispers. Hulogosi Press, Eugene, Oregon.

Hernández E., Crum H., Fox W. and Sharp A. 1951. A unique vegetational area in Tamaulipas. Bulletin of the Torrey Botanical Club 78:458-463.

Matuda E. 1953. Plantas asiáticas en México. Memorias del Congreso Científico Mexicano 6:230-248.

Miranda F. and Sharp A.J. 1950. Characteristics of the vegetation in certain temperate regions of eastern México. Ecology 31:313333.

Patterson T.1988. A new species of Picea (Pinaceae) from Nuevo León, México. Sida 13:131-135.

Puig H., Bracho R. and Sosa V. 1987. El bosque mesófilo de montaña: composición florística y estructura. In: Puig H. and Bracho R. Eds. El Bosque Mesófilo de Montaña de Tamaulipas, pp. 55-79, Instituto de Ecología, México, D.F.

Rushforth K. 1987. Conifers. Facts on File, New York.

Schlechtendal D.F.L von. 1838. Verläufige Nachricht über die Mexikanischen Coniferen. Linnaea 12: 486-496.

Vance N.C. and Krupkin A.B. 1993.Using restriction fragment length polymorphisms to assess genetic variability among yew taxa. In: Temple C.R. Ed. International Yew Resources Conference: Conservation Biology and Interactions. Native Yew Conservation Council, Berkeley, CA., 12-13 March 1993, Berkeley, California.

Wheeler N., Jech K., Masters S., Brobst S., Alvarado A. and Hoover A. 1992. Effects of genetic, epigenetic, and environmental factors on taxol content in Taxus brevifolia and related species. Journal of Natural Products 55:432-440.

Witherup K., Look S., Stasko M., Ghiorzi T., Muschik G. and Cragg G. 1990. Taxus spp. needles contain amounts of taxol comparable to the bark of Taxus brevifolia: analysis and isolation. Journal of Natural Products 53:1249-1255.

Fecha de recepción: 30 de abril de 2002

Versión corregida: 30 de abril de 2003

Aceptado: 3 de mayo de 2003 